
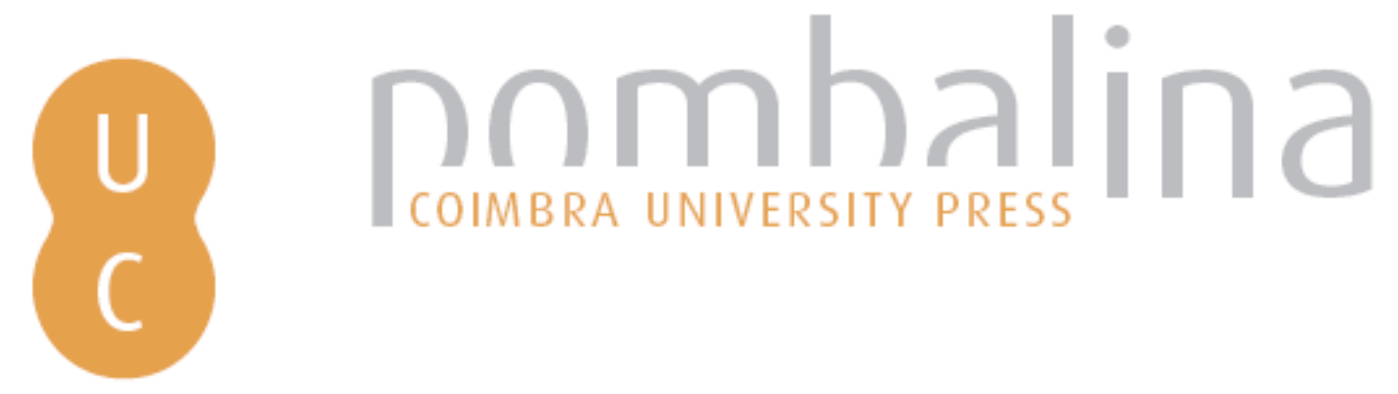

\title{
Moral-related issues about participation of children and youth in modern sport: prologue for a tribute to Martin Lee
}

\author{
Autor(es): $\quad$ Gonçalves, Carlos Eduardo \\ Publicado por: Imprensa da Universidade de Coimbra \\ URL \\ persistente: URI:http://hdl.handle.net/10316.2/32229 \\ DOI: $\quad$ DOI:http://dx.doi.org/10.14195/978-989-26-0474-9_1 \\ Accessed : $\quad$ 26-Apr-2023 12:44:27
}

A navegação consulta e descarregamento dos títulos inseridos nas Bibliotecas Digitais UC Digitalis, UC Pombalina e UC Impactum, pressupõem a aceitação plena e sem reservas dos Termos e Condições de Uso destas Bibliotecas Digitais, disponíveis em https://digitalis.uc.pt/pt-pt/termos.

Conforme exposto nos referidos Termos e Condições de Uso, o descarregamento de títulos de acesso restrito requer uma licença válida de autorização devendo o utilizador aceder ao(s) documento(s) a partir de um endereço de IP da instituição detentora da supramencionada licença.

Ao utilizador é apenas permitido o descarregamento para uso pessoal, pelo que o emprego do(s) título(s) descarregado(s) para outro fim, designadamente comercial, carece de autorização do respetivo autor ou editor da obra.

Na medida em que todas as obras da UC Digitalis se encontram protegidas pelo Código do Direito de Autor e Direitos Conexos e demais legislação aplicável, toda a cópia, parcial ou total, deste documento, nos casos em que é legalmente admitida, deverá conter ou fazer-se acompanhar por este aviso.

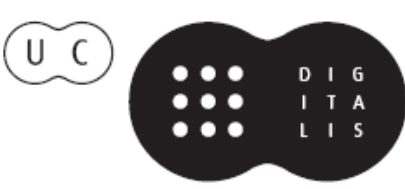


Carlos Eduardo Gonçalves

Sean P. Cumming

Manuel J. Coelho e Silva

Robert M. Malina

(Editors)

\section{Sport \\ and Education}

Oribute to OMaxtin Lee

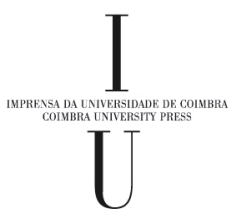


Carlos Eduardo Gonçalves

University of Coimbra, Portugal

\section{MORAL-RELATED ISSUES ABOUT PARTICIPATION OF \\ CHILDREN AND YOUTH IN MODERN SPORT - prologue for a tribute to Martin Lee}

\section{Sport and moral universalism}

The issues raised by the mass participation in sport by children and young people were not on the agenda of the "founder" of modern sport. Baron de Coubertin, despite including the concept of fair play in the genetic code of sport, was addressing a quite different public to the children and young people who today account for such a large proportion of the sporting population. However, over the century and half that modern sport has been in existence, the notion that physical activity is of educational value (not only physically but also morally) has always been present (Keating, 2001); indeed, it continues to provide a justification for the promotion and organisation of sport amongst young people. The backdrop to this is of course the enormous media coverage that is given to professional sport around the world; and consequently, tens of millions of children and young people are being encouraged to take up sporting activity at ever younger ages (Ewing \& Seefeldt, 2002).

Despite this, sport today is widely perceived as somewhat degenerate in relation to the golden age of Coubertin, when it was engaged in for its own sake, in the pure disinterested spirit of the aristocratic fair play. Today the competitive ethos has won out over the educational aspect of sport, after decades of tense conflict between the two. Morgan (2001) complains: "sport rules have become little more than technical directives that enable participants to acquire the external goods they seek. Any moral power the rules of sports once had has disappeared". For an activity that considers itself as fair and meritocratic, the consequences of this may be the development of attitudes of complacency and cynicism.

Indeed this is the posture that many scholars, coaches and other sporting agents adopt when they concur that sports provide a context for the sanctioned expression of violence. But that same context frequently encourages the unsanctioned expression of violence (in which Lee's concept of gamesmanship is rooted). If sports are conducive to violent behavior and aggressive conduct, that is because we want them to be. Spectators expect tough aggressive behaviour from the athletes, which, while not exactly considered violence in its purest form, is often closely connected to it. Furthermore, 
Cashmore (2005) argues that "the findings of Bandura are totally at odds with the view of many coaches and players who believe that sports are a good way of letting off steam, or getting our aggression out of our system." Thus, aggressive and tendentially violent behaviour is acquired through the social learning process, in interaction with others.

The emergence of sport for children and youth as a mass phenomenon has once more brought fair play back to the heart of the educational process. Can this tension between competitiveness and education be resolved within sports training? The proliferation of references, so visible in the world of sport, means that these issues have to be negotiated and renegotiated between the various subjects or actors involved in any given sporting encounter. This makes it impossible to distinguish the causes and effects as regards what has been taught in training sessions and what has in fact been learned by the young athletes.

The study of morality in sport clearly reflects this theoretical and methodological problem. Sports morality, as discussed in the studies of Shields \& Bredemeier (1995) and Shields, Bredemeier \& Powell (2002), has specific characteristics that are not easily transferred to daily life. Bredemeier (1999) following Kohlberg, suggests that sports teams should take on the role of moral communities. But what should be the universal morality adopted? The various moralities existing within the team, resulting from established hierarchies, may not be generalizable or desirable. The initial content of messages may be received differently by different people in accordance with the filters (hierarchical, ethnic, etc) conditioning their perceptions, thereby causing them to multiply into a host of individualized versions (Weiss \& Smith, 2002; Gonçalves et al., 2005).

\section{Educational justifications for sport}

Viewed from the outside, sport appears to be caught up in the whirlpool of contradictory tendencies that mark postmodern globalization. It is included in the Rights of the Child (David, 2005), is medicalized, and commodified, becoming an article of consumption to be used by the body, but subordinated to it (Anderson, 2006; Beja Santos, 2006).

For some scholars, it seems sport is under siege, surrounded by extrinsic justifications, arguing that sport as human practice is not sustainable when the extrinsic goods of wealth and fame are dominant (Kirk, 2006). From this point of view, physical education and youth sport are viewed as of secondary importance to other social goods such as health or economic and social aspects of life.

In this context, fair play lingers on only as an expression of the politically correct. For this reason, it is of the utmost importance that sport, which is for the wellbeing of young people, is introduced to them as young as possible, so that the effects will be profound and longlasting. After a long period when it seemed to have been extinguished, sport education is returning to reclaim its role as the promoter of virtue and moral education. 


\section{Youth sport as moral practice}

On this basis, all training and competition may be considered to have an ethical dimension, as it is oriented towards training the subject for life, alongside the other aspects of general education. Athletes are encouraged to take morally correct decisions, which express high levels of autonomous moral judgment.

There are two problems with this argument, however. Firstly, the fact that certain individuals may have high levels of moral judgment does not necessarily mean that they will behave in a correspondingly moral way in training or in competition. Secondly, it may be that the ecological conditions in the club or team are not propitious to the moral stance proposed by the coach, or that unexpected situations come up in the competitive context (concerning the role of the adversary, the uncertainty of the result, interventions by the referee or the public, etc) in which the moral judgments learned may not be applied.

Thinking of sport only in terms of a moral language inevitably leads us to neglect the role played by conflicts, power and vested interests in sports competition. At the same time, failure to take account of the power relationships that exist in decisionmaking processes in sport will distort the reality, covering it in a veil of rationality that may be accessible to the autonomous individual, perfectly able to exercise his own moral judgment independently, but unsuitable for the child or young person immersed in the highly complex relations of the sporting context.

Martin Lee's studies, though embarking from different methodological assumptions, reveal a close philosophical affinity with Kant's categorical imperative, which postulates perfect homogeneity between a subject's biography and work, as a consequence of the absolute subordination of life to reason.

However, as we have already seen, the young athlete is confronted with a series of constraints and contradictions (power relations, ecological environment, the ups and downs of sporting practice itself, etc) which limit his choices and bring about a rupture between free will/reason and conditioned behaviour. In this situation, the uncritical assumption of the positivist paradigm as a scientific tool may lead to a distortion of reality (Brustad, 2002). This is why multi-method studies are so important, with qualitative research complementing or even orienting quantitative research in the the quest for a better understanding of the phenomenon (Krane \& Baird, 2005), and the refusal to separate cognitive values from ethical and political ones.

In both his earlier and more recent studies, Lee (2005; this volume) has always been aware of these difficulties and has demonstrated remarkable intellectual openness to new lines of research and methodologies. His concern remains as to how to transfer the knowledge acquired through research to the agents that work in the field of children's and youth sport, particularly their coaches (Lee, 1998). For this reason, his research has functioned as a stimulus for further study of moral issues in sport, leading to this volume, amongst other developments.

The fears of an ethical drift in the field of sport, caused by unrestrained market forces, bad practices, unhealthy atmospheres in training and competition, or by poor management of certain phases of the training process, are offset by complaints on the part of many coaches and sporting professionals that sport has been hijacked to be used 
as a vehicle for the promotion of health or as a tool to prevent or treat social ills. In this context, such epistemologically-open academic research, despite its commitment to sport at the service of child and youth development, provides a vital contribution to our knowledge of the subject and to the potential for change.

Several approaches of the issues raised by youth sport are presented in this volume. The complexity of the themes is discussed by the authors starting from their respective scientific fields, but never forgeting the global perspective, namely that sport can not be reduced to the learning of motor skills and tactics and that education is more than the transmission of knowlegde. The contemporary world presents new problems at an unpredictable rate. Families, coaches, sport organizations, and young athletes face uncertain challenges. The authors' experience and the high quality of the research represent, once again, a strong statement in favor of the vital connection between sport and education.

\section{References}

Anderson P (2006). Carnal capital. New Left Review, 39, May-June.

Beja Santos M (2006). O moderno Proteu da sociedade da hiperescolha. Le Monde Diplomatique, 2, II série, Dezembro.

Bredemeier B (1999). Youth Sports as a Moral Community. In R Malina (Ed.), Proceedings of the Congress: Youth Sports in the 21st Century. East Lansing, Michigan State University, The Institute for the Study of Youth Sports.

Brustad R (2002). A critical analysis of knowledge construction in sport psychology. In T Horn (Ed), Advances in Sport Psychology (pp 243-279). Champaign, Ill: Human Kinetics.

Cashmore E (2005). Making Sense of Sports (4th edition). Oxon, Routledge.

David P(2005). Human Rights in Youth Sport: a critical review of children's rights in competitive sports. Oxon, Routledge

Ewing M, Seefeldt V (2002). Patterns of participation in american agency-sponsored youth sports. In FL Smoll, RE. Smith (Eds.), Children and Youth in Sport: a Biopsychosocial Perspective (pp.39-60). Dubuque, Kendall/Hunt.

Keating JW (2001). Sportsmanship as a moral category. In WJ Morgan, KV Meier, Angela J. Schneider (Eds.), Ethics in Sport (pp.7-20). Champaign, Il, Human Kinetics.

Kirk D (2006). Sport education, critical pedagogy, and learning theory: toward an intrinsic justification for physical education and youth sport. Quest, 58, 255-264.

Krane V, Baird SM (2005). Using ethnography in applied sport psychology. Journal of Applied Sport Psychology, 17, 87-107.

Morgan W (2001). Patriotic sports and the moral making of nations. In WJ Morgan, KV Meier, AJ Schneider (Eds.), Ethics in Sport (pp. 370-392). Champaign, Il, Human Kinetics.

Shields D, Bredemeier B (1995). Character Development Through Physical Activity. Champaign, Ill., Human Kinetics.

Shields D, Bredemeier B, Power F (2002). Character development and children's sport. In F Smoll \& R Smith (eds), Children and Youth in Sport: a Biopsychosocial Perspective.(pp. 537-563) Dubuque. Kendall/Hunt.

Weiss M, Smith A (2002). Moral development in sport and physical activity: theory, research, and intervention. In T Horn (Ed), Advances in Sport Psychology (pp 243-279). Champaign, Ill: Human Kinetics. 